\title{
Habitats, Local Distribution and Utilization of Some Marine Bivalves of Mon Coastal Area in Myanmar
}

\author{
Naung Naung Oo \\ Department of Marine Science, Sittway University, Rakhine State, Myanmar
}

Corresponding Author Email: naungnaungoomarine@gmail.com

https://doi.org/10.18280/eesrj.070206

Received: 20 January 2020

Accepted: 13 February 2020

\section{Keywords:}

bivalve shells, intertidal area, hard clams, oysters, mussels, commercial species

\begin{abstract}
A total of 28 taxa belonging to 18 genera, 16 families and 6 orders under the class Bivalvia of the phylum Mollusca were presently identified. These specimens included 2 species of Anadara, 1 species of Perna, 1 species of Placuna, 2 species of Crassostrea, 1 species of Saccostrea, 1 species of Lucina, 1 species of Trachycardium, 3 species of Mactra, 2 species of Pharella, 1 species of Solen, 1 species of Tellina, 2 species of Donax, 2 species of Gari, 1 species of Azorinus, 3 species of Polymesoda, 2 species of Meretrix, 1 species of Pholas and 1 species of Bactronophorus. Among the collected specimens, Saccostrea species were represented as a dominant species followed by Meretrix and Mactra species within the study period. In all study areas, Kawmawkinn station of Ye River Mouth area is more dominant than other stations. Moreover, habitats, local distribution and utilization of each species were also presented.
\end{abstract}

\section{INTRODUCTION}

Bivalves are among the most fascinating groups of molluscs that for centuries have attracted hobbyists, business men, ecologists and scientists among others from around the globe.

The south-eastern portion of the central deltaic area comprises the coast of Mon State. Here, the Thanlwin River opens into the Gulf of Martaban and Bilukyun (Giant Island) lies at its mouth. Mon coastal water is rich in many economically important species of fishes, shrimps, oysters, clams and mussels along the coastal waters. The flesh of many species is eaten by man. Although molluscs are of huge importance to the ecosystem and the society, not much is known about the seashells of Mon coastal water. The bivalves of Mon coastal water including as the Ark shells, Mussels, Windowpane shells, Oysters, Lucinas, Cockles, Trough shells, Knife and razor clams, Tellins, Donax clams, Sunset clams or Sanguins, Short razor clams, Marsh clams, Venus clams, Angel wings or Piddocks, Shipworms, and some others.

Molluscs have for many centuries been the source of important luxury goods, notably pearls, mother of pearl, Tyrian purple dye, and sea silk. Their shells have also been used as money in some pre-industrial societies. Many bivalves are edible, and as such as are sought after and economically important. In modern time many more bivalve species are harvested, farmed and cultivated, including rocky-oyster, mussels and clams.

Bivalves provide an important source of income to many coastal communities in Mon State. As well as being utilized for food, specimens are in demand for ornamental and shellcraft industry. There are indications, however, that marine molluscs in the region have both diminished in number and size over the years. This has been attributed to increased consumption by a growing human population and a great number of gatherers.
The objectives of this study are 1) to record bivalve species in Mon coastal area, and 2) to observe the habitats, distribution and utilization of marine bivalves from intertidal waters of Mon coastal area.

\section{MATERIALS AND METHODS}

\subsection{Study area}

Mon coastal area is located between (Lat. $14^{\circ} 55^{\prime} \mathrm{N}$ and $16^{\circ}$ $35^{\prime} \mathrm{N}$ and Long. $97^{\circ} 20^{\prime} \mathrm{E}$ and $97^{\circ} 48^{\prime} \mathrm{E}$ ) with a unique ecosystem which extends $320 \mathrm{~km}$ from the mouth of Sittaung River in the north to Kyungyi Island, Ye Township in the south. The areas studied for this research work include 12 stations in four townships, mainly along the intertidal areas of Mon coast (Figure 1).

\section{Collection in Paung Township includes -}

1 Ahlyat (Lat. $16^{\circ} 31^{\prime} \mathrm{N}$, Long. $97^{\circ} 22^{\prime} \mathrm{E}$ )

Collection in Chaungsone Township includes Sebala (Lat. 16 $16^{\circ} \mathrm{N}$, Long. 97 $30^{\prime} \mathrm{E}$ )

Collection in Thanbyuzayat Township covers -

Kyaikkhami (Lat. $16^{\circ} 04^{\prime} \mathrm{N}$, Long. $97^{\circ} 33^{\prime} \mathrm{E}$ )

Sinpone (Lat. $16^{\circ} 03^{\prime} \mathrm{N}$, Long. $97^{\circ} 33^{\prime} \mathrm{E}$ )

Kaduthtauk (Lat. $16^{\circ} 02^{\prime}$ N , Long. 97 $34^{\circ}$ E)

Setse (Lat. $15^{\circ} 56^{\prime} \mathrm{N}$, Long. $97^{\circ} 37^{\prime} \mathrm{E}$ )

Collection in the Ye Township includes -

Kawdut (Lat. $15^{\circ} 32^{\prime} \mathrm{N}$, Long. $97^{\circ} 45^{\prime} \mathrm{E}$ )

Pagoda Point $\quad$ (Lat. $15^{\circ} 12^{\prime} \mathrm{N}$, Long. $97^{\circ} 46^{\prime} \mathrm{E}$ )

Zeephyuthaung (Lat. $15^{\circ} 12^{\prime} \mathrm{N}$, Long. $97^{\circ} 47^{\prime} \mathrm{E}$ )

Kamawkinn (Lat. $15^{\circ} 12^{\prime} \mathrm{N}$, Long. $97^{\circ} 49^{\prime} \mathrm{E}$ )

Sitaw (Lat. $15^{\circ} 11^{\prime} \mathrm{N}$, Long. $97^{\circ} 48^{\prime} \mathrm{E}$ )

Kabyarwa $\quad$ (Lat. $15^{\circ} 04^{\prime} \mathrm{N}$, Long. $97^{\circ} 48^{\prime} \mathrm{E}$ ) 


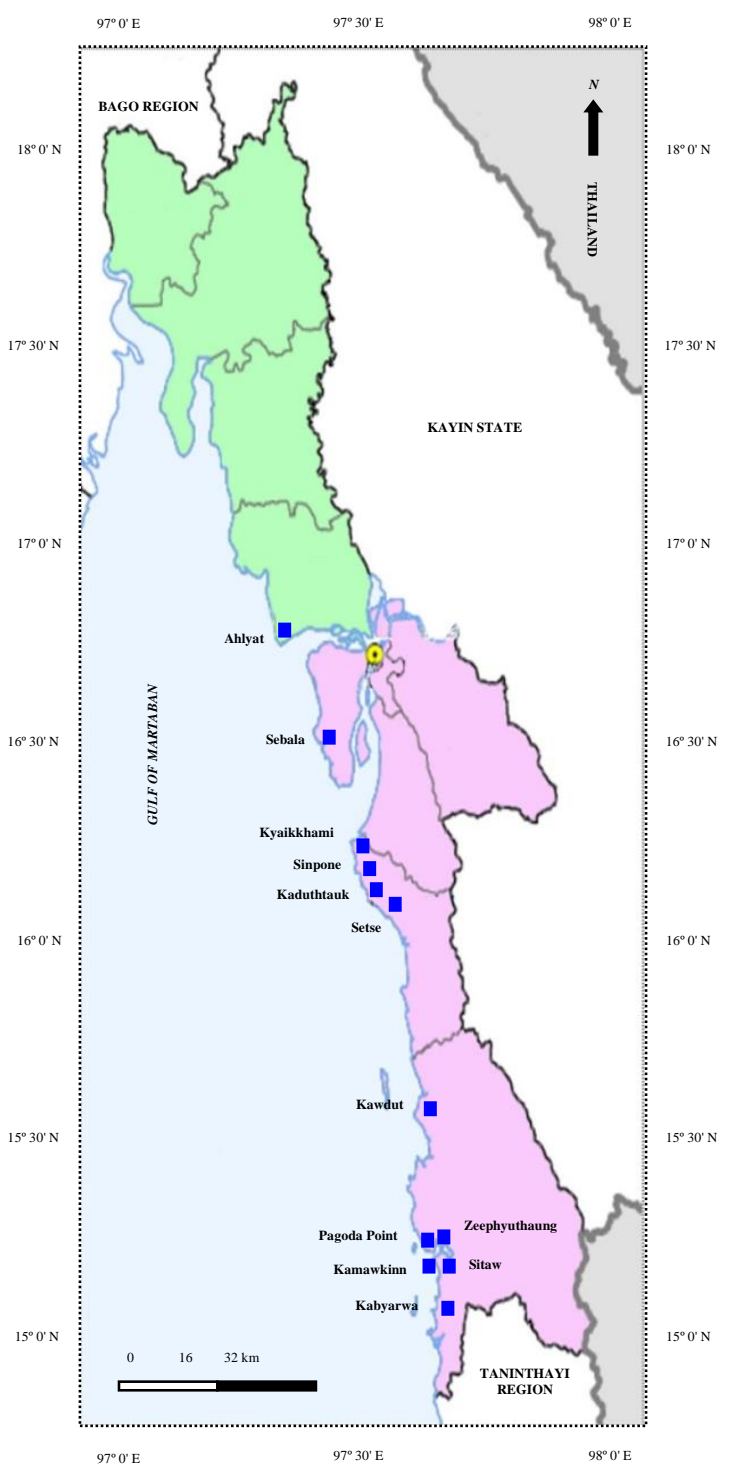

Figure 1. Map showing the collection sites of bivalve molluscs in Mon coastal area

\subsection{Study period}

Specimens of the bivalve shells were collected from mangrove swamps, rocky substrate, sandy shore and mud flat areas in upper intertidal to subtidal zones along the Mon coastal areas from December 2018 to November 2019.

\subsection{Field study}

Habitats for each shell have been found as subtidal (below the low tide line), intertidal (between the tide lines), moderately shallow (littoral zone) and moderately deep (sublittoral), respectively. The best time to collect is of course at low tide, when one can set out to the low water limits. Any stone, plant or section of drift wood are turned over and searched for hiding molluscs. Many of the molluscan fauna collections were made by a shovel, a pair of forceps and hand.

A large majority of shells are wave-worn, eroded, broken, or otherwise imperfect. Nevertheless, the collecting of dead shells is not to be neglected altogether, since some fine examples may be obtained thus. A bag or sack in which to put specimens, a medium-sized transparent plastic container to put fragile specimens, and alive ones. All of the specimens were preserved in $10 \%$ formaldehyde-seawater. Local distribution of bivalves was recorded and zoogeographical distribution of each species were prepared with the data from the literature available. Habitat, utilization, ecological notes and associated species of bivalves were also recorded in the field.

\subsection{Laboratory study}

Bivalve shells that have been collected previously are to be cleaned. The first thing to do is to get rid of the animal in the shell. The common practice is to place the shells in a pan of water, bringing them to a boil, keeping 10-15 minutes. The epifaunas and periostracum were removed by soaking the shells in a solution of caustic soda. After all the shells were cleaned, washed, dried, and ready for storage. And then, the precise locality and date, collector name, habitat, classification of shell and catalogue number are recorded in label slip for each shell. External and internal morphological structures were used as taxonomic criteria of the bivalve shells and photographed with a digital camera.

Terminology, various conchological features and identification of the genus and species of the prepared selected shells together with the drawing made and notes taken were worked out according to Morris [1], Melvin [2], Lim [3], Hinton [4], Lindner [5], Springsteen and Leobrera [6], Abbott [7], Millard [8], Poutiers [9], Oliver [10], Roger and Novi [11], Hossain et al. [12] and WoRMS (World Register of Marine Species) [13].

\section{RESULTS AND DISCUSSION}

\subsection{Systematic of bivalve shells in Mon coastal area}

There were 28 species of bivalve shells from different habitats of rock substrates, mangrove swamps, river mouth estuarine areas, sand dunes and mud flats found along the intertidal and shallow subtidal zone of Mon coastal area.

Phylum: Mollusca Linnaeus, 1758

Class: Bivalvia (= Pelecypoda) Linnaeus, 1758

Order: Arcoida Stoliczka, 1871

Family: Arcidae Lamarck, 1809 Ark shells

Genus: Anadara Gray, 1847

Species: A. antiquata (Linnaeus, 1758)

Species: A. granosa (Linnaeus, 1758)

Order Mytiloida Ferussac, 1822

Family: Mytilidae Rafinesque, 1815 Mussels

Genus: Perna Philipsson, 1788

Species: P. viridis (Linnaeus, 1758)

Order: Pectinida Gray, 1854

Family: Placunidae Gray, 1842 Windowpane shells

Genus: Placuna Lightfoot, 1786

Species: P. placenta (Linnaeus, 1758)

Order: Ostreida Fèrussac, 1822

Family: Ostreidae Rafinesque, 1815 Oysters

Genus: Crassostrea Sacco, 1897

Species: C. belcheri (Sowerby, 1871)

Species: C. rhizophorae (Guilding, 1828)

Genus: Saccostrea Dollfus \& Dautzenberg, 1920

Species: S. cuccullata (Born, 1778)

Order: Veneroida H. Adams \& A. Adams, 1856

Family: Lucinidae Fleming, 1828 Lucinas 
Genus: Lucina Bruguiére, 1797

Species: L. corrugata (Deshayes, 1843)

Family: Cardiidae Lamarck, 1809 Cockles

Genus: Trachycardium Mørch, 1853

Species: T. rugosum (Lamark, 1819)

Family: Mactridae Lamarck, 1809 Trough shells

Genus: Mactra Linnaeus, 1767

Species: M. luzonica Reeve, 1854

Species: M. maculata Gmelin, 1791

Species: $M$. mera Reeve, 1854

Family: Solenidae Lamarck, 1809 Knife and

razor clams

Genus: Pharella Gray, 1854

Species: P. acutidens (Broderip and

Sowerby, 1828)

Species: P. javanica (Lamarck, 1818)

Genus: Solen Linnaeus, 1758

Species: S. roseomaculatus Pilsbry, 1901

Family: Tellinidae Blainville, 1814 Tellins

Genus: Tellina Linnaeus, 1758

Species: T. virgata Linnaeus, 1758

Family: Donacidae Fleming, 1828 Donax clams

Genus: Donax Linnaeus, 1758

Species: D. cuneatus Linnaeus, 1758

Species: D. faba Gmelin, 1791

Family: Psammobiidae (= Gariidae) Fleming,

1828 Sunset clams or Sanguins

Genus: Gari Schumacher, 1817

Species: G. elongata (Lamarck, 1818)

Species: G. togata (Deshayes, 1855)

Family: Solecurtidae d'Orbigny, 1846 Short razor clams

Genus: Azorinus Récluz, 1869

Species: A. abbreviatus (Gould, 1861)

Family: Corbiculidae Gray, 1847 Marsh clams

Genus: Polymesoda Rafinesque, 1828

Species: P. bengalensis (Lamarck, 1818)

Species: P. erosa (Lightfoot, 1786)

Species: P. expansa (Mousson, 1849)

Family: Veneridae Rafinesque, 1815 Venus clams

Genus: Meretrix Lamarck, 1799

Species: M. lyrata (Sowerby, 1851)

Species: M. meretrix (Linnaeus, 1758)

Order: Myoida Stoliczka, 1870

Family: Pholadidae Lamarck, 1809 Angel wings or Piddocks

Genus: Pholas Linnaeus, 1758

Species: P. orientalis Gmelin, 1791

Family: Teredinidae Rafinesque, 1815

Shipworms

Genus: Bactronophorus Tapparone Canefri, 1877

Species: B. thoracites (Gould, 1856)

\subsection{Habitats, local distribution and utilization of bivalve shells in Mon coastal area}

Mon coastal area is rich in brackish-water bivalves. In this study, 28 species of brackish-water bivalves were found based on their habitats, local distribution and utilization along the shallow water intertidal zone of Mon coast.

Ark shells (Thwe-gone/Gone/Gyin) were sedentary animals, living attached to the substrate by means of their fringe-like byssus and sometimes nestling in rock crevices, or unattached and often more or less buried in soft bottoms. The presence of haemoglobin enables them to colonize habitats of low oxygen concentration. Arcidae are actively collected for food in the area; species of Anadara represent major commercial species and collectively known as "blood cockles".

Mussels (Bae-wun) were sedentary animals, mainly attached to hard substrates by their well-developed byssus, sometimes nestlers, coral and rock borers, or associated with ascidians. Many species of this family are collected in the area for human consumption, food for animals, or as baits. Some mytilids represent now days major commercial species and aquaculture has strongly developed in many regions to keep up with increasing demand.

Windowpane shells (Tha-byar/ Ka-byar) were suspension filter-feeding species, living unattached on the surface of muddy flats in shallow water, lying generally on the right valve. Placunidae are extensively collected in the Indo-West Pacific, and cultivated in several areas, for their translucent shell, originally as a substitute of glass in glazing, now mainly for the manufacture of trays, lamp-shades and numerous decorative items. The flesh is often used for food by coastal populations.

Oysters (Ka-mar) were suspension filter-feeding animals, living cemented to the substrate by the left valve, mainly in littoral and shallow subtidal areas. The Ostreidae include some of the most important commercial species of bivalves, and are intensively cultured in many parts of the area.

Lucinas (Kha-yu-kyar) were burrowing, detritus-feeding animals, in which the inhalant siphon is usually replaced by an anterior tube lined with mucus and constructed within the substrate by the extensible, worm-like foot. The Lucinidae typically occur in sulphide-containing reduced sediments. The presence of the respiratory pigment haemoglobin enables them to live in these habitats of low oxygen concentration.

Symbiotic, sulphur-oxydizing chemautotrophic bacteria are frequently housed in their thick gills and make a substantial contribution to their nutrition. Some of the larger and most common species are artisanally fished in some areas, and appear frequently in local markets, notably in Ahlyat and Sebala areas.

Cockles (Gone-yat-taung) were shallow burrowers in sandy to muddy bottoms, most common in littoral and shallow subtidal waters. The geniculate foot can be used for jumping to escape predators. In the tropical West Pacific, cockles are mainly collected for their shells, which are used as decorative items in local shellcraft. They are also eaten by coastal people and occasionally appear in local markets.

Trough shells (Sin-hnar-maung) were active burrowers of sandy to muddy bottoms. Suspension filter-feeding animals. Mactridae represent generally species of secondary importance in the harvest of edible bivalves in the area, although a few species are quite regularly fished locally.

Knife and razor clams (Thin-don-kha-yu) were filterfeeding animals, adapted to swift and deep-burrowing in soft bottoms with their powerful foot, capable of swelling at the end and protruding anteriorly through the narrowly elongate shell. Intertidal species of Solenidae are sometimes actively exploited, notably in the Philippines, Indonesia, and Malaysia.

Tellins (Moe-thee) were active burrowers of soft substrates in which they may constitute dense communities, sucking up organic matter from the sea floor with their long siphons. Lay frequently in a horizontal position within the substrate, with the left valve uppermost. Tellins are collected for food by 
coastal populations in many areas, and their delicate and often colourful shells are frequently used to make decorative items.

Donax clams (Pè-late-pyar) were quick shallow burrowers living in sandy bottoms, often under the influence of surf. Both suspension and deposit feeding animals. Locally exploited by coastal people in the area. A single species is known to be collected in fairly large quantities in the Philippines.

Sunset clams or sanguins (Gone-kyar) were deposit or suspension feeding animals, generally lying buried at an oblique angle to the surface, with tips of siphons reaching the sea bottom. Can actively burrow in soft substrates with their strong foot. The most common species of Psammobiidae are often collected for food in southeastern Asian countries of the tropical West Pacific, and some are considered a delicacy.

Short razor clams (Yauk-cho) were suspension or deposit feeding animals, actively burrowing in soft bottoms with their powerful foot. Generally collected for subsistence by coastal populations in the area. However, a single species is of economic importance in Thailand.

Marsh clams (Gone-mae/Gone-nyo) were suspension filter feeders, burrowing in soft bottoms of shallow fresh or brackish water areas. Used locally for subsistence.

Venus clams (Shut) were active burrowers in various soft bottoms, sometimes nestling in rock crevices or among marine growths. Most common in low intertidal to shallow subtidal depths, especially in areas where organic debris is present in high concentration. Suspension feeders, filtering planktonic algae and organic matter from the water. In the area, many species of Veneridae are collected for food or commercially fished, sometimes in large quantities. Some represent major commercial species and are extensively cultivated to keep up with high demand and to compensate for effects of over exploitation and increasing pollution of coastal environments.

Angel wings or piddocks (Sue-phyu) were highly specialized bivalves adapted for boring into relatively hard substrates such as limestone, sandstone, stiff clay or wood. Filter-feeding animals. Some Pholadidae are known for causing severe damage to rocky or wooden structures in harbours and other coastal areas. A number of species are collected for food (one is of commercial importance in the Philippines), and are often considered a delicacy.

Shipworms (Thin-baw-phauk) were highly specialized bivalves adapted for boring into submerged wood and other plant materials. Filter-feeding animals, alternating spells of feeding on plankton with periods of utilization of rasped wood particles, initially digested by symbiotic bacteria. Internal calcareous lining of burrows probably preventing shipworms from intersecting one another. Shipworms are generally well known for causing damage to shipping and harbour wooden structures. However, they are also locally used for human consumption in the area.

Molluscs both of land and shore were among man's first stable sources of protein food. Many have provided a double or even treble bounty offering the uses of their shells and other products as well as the nourishment of their flesh. Of all molluscan foods, the taste of oysters is the most delicate and nutritious. Oysters of various kinds are eaten throughout the world wherever they occur and so are mussels, particularly the widespread and prolific edible mussel Perna viridis (Bae-wun) Even more nutritious than oysters but not quite so easily digestible, they are usually eaten cooked. In addition to oysters and mussels, there are cockles and hard clams are generally popular for human food.

In Mon coastal area, there are very many ways practical, ornamental, symbolic or emblematic in which shells play their part in the human scene. Many of these uses are obsolete, some have declined, but others continue and new ones are invented as the ingenuity of man devises fresh ways of employing and enjoying these versatile creatures. The commercial species of bivalve shells in Mon coastal area were listed and shown in Table 1 with their prices and Figure 2.

Table 1. Commercial species of bivalve shells in Mon coastal area

\begin{tabular}{cc}
\hline Species & Price (MMK) 1 kg \\
\hline Anadara granosa (Thwe-gone/ Gyin) & 25000 \\
Perna viridis (Bae-wun) & 30000 \\
Crassostrea belcheri (Ka-mar) & 45000 \\
Mactra luzonica (Sin-hnar-maung) & 6000 \\
Pharella acutidens (Thin-don-kha-yu) & 20000 \\
P. javanica (Thin-don-kha-yu) & 20000 \\
Solen roseomaculatus (Thin-don-kha-yu) & 20000 \\
Azorinus abbreviatus (Yauk-cho) & 20000 \\
Polymesoda bengalensis (Gone-mae) & 18000 \\
P. erosa (Gone-mae) & 18000 \\
P. expansa (Gone-nyo) & 18000 \\
Meretrix lyrata (Shut) & 10000 \\
M. meretrix (Shut) & 10000 \\
\hline
\end{tabular}

The total diversity of bivalves recorded from 12 study sites of the rocky fringe, mudflat, sand flat and mangrove swamp in Mon coastal area. The study period covers from December 2018 to November 2019. Though marine bivlaves consisting 16 families were recorded from Mon coastal area, such as Arcidae, Mytilidae, Placunidae, Ostreidae, Lucinidae, Cardiidae, Mactridae, Solenidae, Tellinidae, Donacidae, Psammobiidae, Solecurtidae, Corbiculidae, Veneridae, Pholadidae and Teredinidae. In this investigation, 28 species of brackish-water bivalves were found along the Mon coastal area.

The family Arcidae consists of 2 species with single genus. The hinge lines are relatively short, strong or beaded radial ribs are found on the shells of Anadara. Anadara antiquata and $A$. granosa are flooded along the Mon coastal area. The family Mytilidae includes single species Perna viridis with strong hinge teeth. The family Placunidae with only one genus Placuna and single species. The valves in the Placuna placenta is different from the others because of its very fine and thin shell. The shell consists of two flattened valves with two diverging teeth on the right valve to fit into two corresponding grooves on the left one. The family Ostreidae which has two genera Crassostrea and Saccostrea and three species. It has a very strong ligament and very thick shell. The family Lucinidae has relatively elongated posterior muscle scar. The shell of Lucina is small, very thin and smooth and teeth are absent.

In the family Cardiidae, the shell is relatively thick and the lateral tooth is present. The family Mactridae has shell without externally distinct ligament and the teeth are large and strong but the family Tellinidae has shell with externally distinct ligament and the teeth are small and weak. The family Solenidae has two genera of Pharella and Solen which has only tooth in each valve. The shells are truncate in front and usually at both ends and greatly elongated as a rule. Pharella acutidens, $P$.javanica and Solen roseomaculatus is commonly found in southern parts of Mon coastal area. The family Donacidae has a single genus with two species recorded from the Mon coastal area. Donax faba and D. cuneatus is flooded along the sampling areas. 

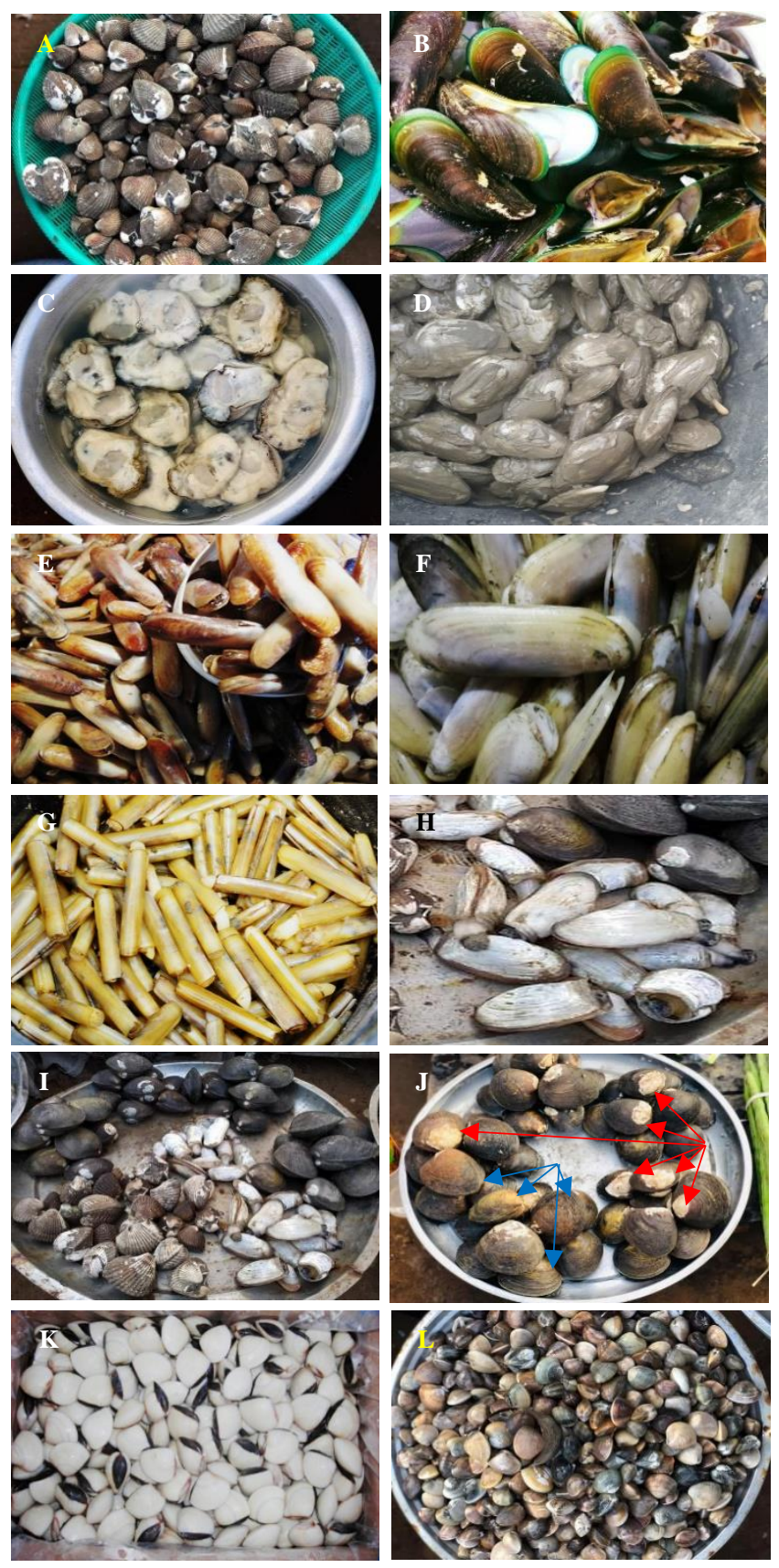

Figure 2. Commercial species of bivalve shells in Mon coastal area. (A) Anadara granosa (Thwe-gone/ Gyin), (B) Perna viridis (Bae-wun), (C) Crassostrea belcheri (Ka-mar),

(D) Mactra luzonica (Sin-hnar-maung), (E) Pharella acutidens (Thin-don-kha-yu), (F) P. javanica (Thin-don-kha-

$\mathrm{yu}),(\mathrm{G})$ Solen roseomaculatus (Thin-don-kha-yu), $(\mathrm{H})$

Azorinus abbreviatus (Yauk-cho), (I) Polymesoda

bengalensis (Gone-mae), (J) P. erosa (Gone-mae) (RED

ARROW) and $P$. expansa (Gone-nyo) (BLUE ARROW),

(K) Meretrix lyrata (Shut), (L) M. meretrix (Shut)

The family Psammobiidae consists of single genus and two species but the family Solecurtidae has only species of Azorinus abbreviatus. The family Corbiculidae has three species such as Polymesoda bengalensis, $P$. erosa and $P$. expansa which are commercial species in Mon coastal area. The family Veneridae consists of two species Meretrix lyrata and $M$. meretrix which commonly found in Ye River Mouth and high consumption rate. The family Pholadidae has a single genus with only species Pholas orientalis is rarely found in northern Mon coast. The family Teredinidae has a single genus with only species Bactronophorus thoracites. It is found at wood borer mangrove and brackish-water areas.

In this study records the local distribution of bivalve species of the natural community actually existing in nature, during the time of the investigation and among a variety of environmental stations. Among these brackish-water bivalve, Saccostrea cuccullata was the most common species since it was found in all stations. With the results obtained, more specific studies of the quantitative ecology of these bivalves are needed to confirm these findings.

Habitats and utilization of brackish-water bivalve species in Mon coastal area and in Rakhine, Ayeyawady and Taninthayi coastal areas had moderate similarity, with local consumption and shell craft utilization $[14,15]$. The information available showed that the nature of brackish-water bivalve communities of Mon coastal area, between the habitats and local utilization, featured some similarity, but not high similarity. Concerning shells used by the local people in the station areas investigated, the brackish-water bivalves of Mon coastal area are facing degradation of habitat by human use. Thus, brackish-water shells may be an indicator for studying environmental health impacts in the future.

The economic importance of bivalves species recorded in study areas were Anadara granosa (Thwe-gone/ Gyin), Perna viridis (Bae-wun), Crassostrea belcheri (Ka-mar), Mactra luzonica (Sin-hnar-maung), Pharella acutidens (Thin-donkha-yu), $\quad P$. javanica (Thin-don-kha-yu), Solen roseomaculatus (Thin-don-kha-yu), Azorinus abbreviatus (Yauk-cho), Polymesoda bengalensis (Gone-mae), P. erosa (Gone-mae), P. expansa (Gone-nyo), Meretrix lyrata (Shut) and $M$. meretrix (Shut) (Table 1). Of these species, Crassostrea belcheri (Ka-mar) is highest price for local markets and followed by Perna viridis (Bae-wun) and Anadara granosa (Thwe-gone/ Gyin). These commercially exploited species were also low in numbers. The number of bivalve species in mudflat area is higher than in sandy dune and mangrove swamp.

Myanmar shell dealers are fond of making toys with shells of all sorts. There could be more than 200 species in the manufacturing of such toys. These toys, mostly of cartoon figures fetch a considerable sum of money too [16, 17]. Molluscs, both land and shore, were among man's first stable sources of with protein. Many have provided a double or even triple bounty, offering the use of their shells and other products as well as the nourishment of their flesh. The oyster is certainly the king of all molluscan foods. The flesh of oysters is the most delicate, as nutritious as milk and so easily digested. Oysters of various kinds are eaten throughout the world. Millions of people in the world today live almost entirely on diet of seafood. Many molluscs are eaten raw, simply sprinkled with a little lemon juice or vinegar. Many people prefer them in, their simplest from. But there are hundreds of recipes for cooking them. Scallops can still be found used as dishes for butter jam or sweets or other small foods.

The sharp edges of mussel, clam and oyster shells have also been used by primitive peoples from time immemorial as knives, scrapers and digging tools. Later societies ground and shaped them into fishhooks, hoes, picks, hammers, gouges and a variety of useful implements attached to handles of wood or bone with thongs of fiber of leather.

A great number of useful and beautiful materials made from shells or ornamented with shells were used by people of almost every culture. For personal adornment, shells have surely been more widely used than any other product of nature. There can 
hardly be a woman or girl who has not, at sometimes, possessed a necklace or bracelet, a brooch, a ring or a pair of ear-rings made from shells. Those of the past can be seen in museum everywhere, in antique shops and salerooms; those of today in shops and stores particularly at coastal resorts and tourist centers and in the curio shops of the East. The modern woman who buys a set of shell costume jewellery at a beach resort, buy it only for adornment. Nowadays, molluscs have given endless source of inspiration to the genius whose pleasure is to use them in the many beautiful arts and crafts all over the world [17-20].

\section{CONCLUSION}

The presence study is based on habitats, local distribution and utilization of marine bivalves collected from Mon coastal areas. A total of 28 taxa of bivalves mostly estuaries forms, were observed. Diverse orders of Arcodids and Veneroids outnumbered in the population of bivalves in the region. Of these, oyster, trough shell and venus clam species showed as the high abundant species. Among the study areas, Kamawkinn station in Ye River Mouth area show a relatively high species diversity and relative abundance while compared with other stations of the study.

\section{ACKNOWLEDGMENT}

I am indebted to Dr Win Naing, Rector of Sittway University and Dr Khin Maung Zaw, Pro-Rector of Sittway University, for their encouragement and supports in preparing this work. I am very grateful to Dr Mya Kyawt Wai, Associate Professor and Head of the Department of Marine Science, Sittway University, for her valuable suggestions and constructive criticisms on this study. I would like to express my sincere thanks to colleagues of Field Observation Group, Department of Marine Science, Mawlamyine University, for their kindly help me in many ways during field trips. Many thanks go to Daw Lwin Lwin, Retired Lecturer of the Department of Marine Science, Mawlamyine University, for her assistance in preparations of the manuscript. I would like to thank my beloved parent, U Win Maung and Daw Than Than Aye, for their physical, moral and financial supports throughout this study.

\section{REFERENCES}

[1] Morris, P.A. (1952). A field guide to pacific coast shells. Houghton Mifflin Company, Boston, 296p.

[2] Melvin, A.G. (1966). Sea Shells of the World. Charles E. Tuttle Co., Inc, 167.

[3] Lim, C.F. (1970). A Checklist of the Molluscs of Singapore. Department of Zoology, University of Singapore, Singapore, $46 \mathrm{p}$.

[4] Hinton, A. (1972). Shells of New Guinea and the central Indo-Pacific. Robert Brown \& Associates, Port Moresby and Jacaranda Press, Milton, 94p.
[5] Lindner, G. (1977). Sea shells of the World. Australia \& New Zealand Book Company, Brook Vale., 271p.

[6] Springsteen, F.J., Leobrera, F.M. (1986). Shells of the Philippines. Carfel Seashell Museum, Manila, 377p.

[7] Abbott, R.T. (1991). Seashells of Southeast Asia. Graham Brash, Singapore, 145p.

[8] Millard, V. (1997). Classification of Mollusca: a Classification of World Wide Mollusca. Victor Millard, South Africa, 544p.

[9] Poutiers, J.M. (1998). Bivalves. In: Carpenter KE, Niem $\mathrm{VH}$, editor. FAO Species Identification Guide for Fishery Purposes. The Living Marine Resources of the Western Central Pacific. Volume 1. Seaweeds, Corals, Bivalves and Gastropods. Food and Agriculture Organization, Rome, 123-362.

[10] Oliver, A.P.H. (2004). Guide to Sea Shells of the World. Philip's a division of Octopus Publishing Group Ltd, London, 320p.

[11] Roger, M., Novi, E.Y.D. (2008). The Seashells. Brunei Press Commercial Printing Services, 89p.

[12] Hossain, M.S., Sharifuzzaman, S.M., Chowdhury, S.R., Chowdhury, M.S.N., Sarker, S., Islam, M.R., Talukder, A. (2014). Sea Shells of Bangladesh: Marine Gastropod and Bivalve Molluscs Biodiversity. Centre for Coast, Climate and Communities (Tetra-C), Institute of Marine Sciences and Fisheries, University of Chittagong, 52p.

[13] WoRMS. (2019). Available Source: http://www.marinespecies. org.

[14] Win, P.T.S. (2012). Study on the marine gastropods and pelecypods from Setse and Kyaikkhami coastal areas. Unpublished MSc Thesis, Department of Marine Science, Mawlamyine University, Mawlamyine. Myanmar.

[15] Win, P.T.S. (2013). A study on the marine pelecypods from Mon coastal areas. Unpublished MRes Thesis, Department of Marine Science, Mawlamyine University, Mawlamyine, Myanmar.

[16] Win, P.P.K. (1990). Taxonomic studies on some molluscs trawled off-shore in Myanmar waters. Unpublished MSc Thesis, Department of Zoology, University of Yangon, Yangon. 307.

[17] Sein, M.L.M. (1982). The taxonomy and distribution of Burmese marine bivalves. Unpublished MSc Thesis, Department of Zoology, Art and Science University, Rangoon, Burma.

[18] Tun, S.P. (2016). The composition and distribution of benthic molluscs along southern Taninthayi Coastal Region. Unpublished MSc Thesis, Department of Marine Science, Mawlamyine University, Mawlamyine, Myanmar.

[19] $\mathrm{Nu}, \mathrm{T}$. (1985). Study on the spat fall of Pena viridis (Linnaeus) in Ye River, Mon State, Burma. Unpublished MSc Thesis, Department of Marine Biology, Moulmein Degree Collage, Moulmein, Burma.

[20] Nwe, W.W. (2019). Biology and culture of green mussel Perna viridis (Linnaeus, 1758) from Ye estuary in Mon State. Unpublished PhD. Dissertation, Department of Marine Science, Mawlamyine University, Mawlamyine, Myanmar. 